\title{
TREATMENT OF SPORT INJURIES WITH ACUPUNCTURE: A LITERATURE REVIEW
}

\author{
TRATAMENTO DE LESÕES DO ESPORTE COM ACUPUNTURA:UMA REVISÃO DA LITERATURA \\ TRATAMIENTO DE LESIONES DEL DEPORTE CON ACUPUNTURA: UNA REVISIÓN DELA LITERATURA
}

Luiza Borges Gentil ${ }^{1}$
(Medical Doctor)

1. Prefeitura Municipal de

Florianópolis, SC, Brazil.

\section{Correspondence:}

Avenida engenheiro Max de souza, $\mathrm{S} / \mathrm{N}$, Centro de saúde de Coqueiros, Florianópolis, SC, Brazil. 88080-000. luizagentil@gmail.com

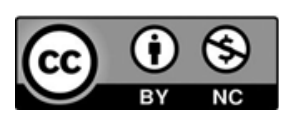

\begin{abstract}
As acupuncture is growing in popularity in Brazil and worldwide, it is necessary to study the benefits and possibilities of this type of treatment more in depth, especially as it is believed to produce fast results with few side effects and does not involve substances banned in sports. Thus, it seems like a good option to be considered as main or adjuvant therapy in sports-related injuries. In order to gain more knowledge about this subject, this article is an integrative review analyzing the publications of the period between January 2012 and January 2017 on the Cochrane and Pubmed platforms that analyzed acupuncture in the treatment of sports injuries. We found 49 articles, 11 of which fulfilled the inclusion criteria: two case reports, three clinical trials and six literature reviews. Although all the articles analyzed produced favorable results with the use of the therapeutic technique in question, flaws in the designs of the studies and the difficulty of creating a placebo control group in acupuncture hinder the qualification of the articles on evidence rating scales. Therefore, it is suggested to the researchers that further studies be published with experimental animal models and observational studies, and that STRICTA recommendations be followed to improve the level of evidence of acupuncture research. Level of Evidence Il; Systematic review of level II studies.
\end{abstract}

Keywords: Acupuncture; Acupuncture therapy; Athletic injuries; Sports medicine.

\section{RESUMO}

Com a popularização da prática de acupuntura no Brasile no mundo, faz-se necessário estudar mais profundamente os beneficios e as possibilidades dessa modalidade de tratamento, especialmente porque a mesma éconsiderada rápida, com poucos efeitos colaterais e isenta de substâncias ilegais na prática esportiva. Dessa forma, parece uma boa opção a ser considerada como tratamento principal ou adjuvante em lesões relacionadas ao esporte. Com o objetivo de ampliar os conhecimentos acerca desse assunto, o presente artigo é um a revisão integrativa, que analisa as publicações no período entre janeiro 2012 ejaneiro de 2017, nas plataformas Cochrane e Pubmed, que analisaram acupuntura no tratamento das lesões esportivas. Foram encontrados 49 artigos, 11 dentre eles preencheram os critérios de inclusão: dois relatos de caso, três ensaios clínicos e seis revisões de literatura. Embora todos os artigos analisados tenham apresentado resultados favoráveis com o uso da técnica terapêutica em questão, fal has nos desenhos dos estudos e a dificuldade de criar um grupo controle placebo em acupuntura prejudicam a qualificação dos artigos em escalas de nível de evidência. Por isso, sugere-se aos pesquisadores que sejam publicados mais estudos com modelos experimentais em animais e estudos observacionais, assim como que sejam seguidas as recomendações STRICTA, para melhorar o nível de evidência das pesquisas em acupuntura. Nível de Evidência; Il Revisão sistemática de estudos de nível II.

Descritores: Acupuntura; Terapia por acupuntura; Traumatismos em atletas; Medicina esportiva.

\section{RESUMEN}

Con la popularización de la práctica de la acupuntura en Brasil y en el mundo, se torna necesario estudiar con mayor profundidad los beneficios y posibilidades deesa modalidad de tratamiento, especialmente porque la misma es considerada rápida, con pocos efectos colaterales y exenta de sustancias ilegales en la práctica deportiva. De esta forma, parece una buena opción a ser considerada como tratamiento principal o adyuvanteen lesiones relacionadas al deporte. Con el objetivo de ampliar los conocimientos sobre este tema, el presente artículo es una revisión integral que analiza las publicaciones del período entre enero 2012 y enero de 2017, en las plataformas Cochrane y Pubmed, que analizaron acupuntura en el tratamiento de las lesiones deportivas. Se encontraron 49 artículos, 11 de ellos cumplieron los criterios de inclusión: dos informes de caso, tres ensayos clínicos y seis revisiones de literatura - nivel de evidencia ll. Aunque todos los artículos analizados han presentado resultados favorables con el uso de la técnica terapéutica en cuestión, fallas en los diseños de los estudios y la dificultad de crear un grupo control placebo en acupuntura perjudican la calificación de los artículos en escalas de nivel de evidencia. Por eso, se sugiere a los investigadores que se publiquen más estudios con modelos experimentales en animales y estudios observacionales, asi como que se sigan las recomendaciones STRICTA para mejorar el nivel de evidencia de las investigaciones en acupuntura. Nivel de Evidencia Il; Revisión sistemática de estudios de nivel II.

Descriptores: Acupuntura; Terapia por acupuntura; Traumatismos en atletas; Medicina deportiva. 


\section{INTRODUCTION}

The practice of acupuncture, including its treatment modalities (such as laser, manual needle and electroacupuncture) are present in more than 140 countries $^{1}$ and have been used to treat athletes and the general population in need of the following: Huang and Ulett have published studies on the analgesic effect of acupuncture ${ }^{2,3}$; Akimoto et al. have studied its efficacy on how to modulate physical well-being 4 ; Wright assessed its use for stress reduction ${ }^{5}$; Shayestehfar assessed its use for reducing pre-championship anxiety ${ }^{6}$; and several other authors have published articles discussing its effects on the levels of endurance required to perform daily activities and to practice sports ${ }^{7-12}$.

This type of therapy is also used to treat musculoskeletal injuries ${ }^{13}$, which are among the most common sports-related injuries: De Almeida et al. used manual acupuncture and electroacupuncture to increase the diameter and the reorganization of collagen fibrils during the first three weeks after the transection of presumed healthy rat tendons ${ }^{14}$; whereas Inoue et al. observed increased cellularity, expression of fibroblast growth factors and transforming growth factor beta, in addition to increased tensile strength of ruptured rat tendons (iatrogenically) exposed to electroacupuncture in relation to controls ${ }^{15}$. These studies suggest that acupuncture may promote cellular function and improve repair of soft tissues following injuries. According to recent literature, acupuncture is considered a minimally invasive method with few side effects, free of elements that could be banned from the World Anti-Doping Agency's list of prohibited substances ${ }^{16}$

Even though $70 \%$ of Chinese athletes refer to acupuncture ${ }^{17}$ as an alternative therapeutic method, its clinical efficacy remains controversial, considering that the significance of results, although positive, has varied at times ${ }^{18,19}$. Huguenin et al., for instance, have conducted a randomized controlled trial with treatment of trigger points on the glutes of several athletes, which has provided enough evidence that there is no difference between acupuncture and placebo ${ }^{20}$.

According to Watts, such doubts will be cleared up soon enough, even though there are scientists who believe that acupuncture is just as effective as placebo. However, several studies have demonstrated that acupuncture releases pain-relieving endorphins, serotonin, which is associated with a sense of well-being, in addition to cortisol, which has anti-inflammatory properties ${ }^{17}$.

In Brazil, acupuncture has also been used in primary health care. In 2006, the Ministry of Health implemented the National Policy on Integrative and Complementary Practices through Ordinance No. 971, with the intention of expanding public access to alternative therapies ${ }^{21}$.
Since then, Brazilians have been treated with Acupuncture and other alternative therapies free of charge; in 2008, roughly 1,340 cities were providing the general public with some sort of integrative and alternative practices through the Unified Health System (SUS) ${ }^{22}$.

Considering the increasing demand for acupuncture therapy and how beneficial it is to athletes in general, the present study aims to gather the articles published through the PuBMed and Cochrane databases between January 2012 and January of the current year, associating acupuncture to the treatment of sports-related injuries in order to broaden the knowledge on this type of therapy within the Sports Medicine environment.

\section{METHOD}

The first stage of this study required the use of the PUBMED database in order to find relevant articles based on keywords such as "acupuncture" and "sports injuries", published in English, Portuguese, Spanish and French between January 22, 2012 and January 22, 2017.

The Cochrane database was also used to find articles published over the same period based on "acupuncture", "sport" and "injuries" as keywords.

Forty-one publications were found including the words searched for on the PubMed platform and 8 publications, on the Cochrane platform.

As shown in Figure 01, the reading of abstracts and the full texts discarded 31 articles from the first platform, which analyzed other aspects of sports-related injuries in addition to their treatment, used another therapy method for those same injuries or used acupuncture for purposes other than that of the study.

The same reading discarded six revisions from the second platform that did not analyze acupuncture as treatment or did not analyze sports-related injuries at all, in addition to one publication that served as protocol for a future study.

\section{RESULTS}

The study designs were separated for analysis according to their classification in the Case Report, Clinical Trial and Literature Review, taking into account their peculiarities.

\section{Case Reports}

In 2013, Woitzik and Kisseltiveram published a case report on a 45-year-old female cyclist with a lymph node cyst in the dorsolateral region of her left foot, which was treated over four acupuncture sessions with needling of the ST36 and LR3 points and electroacupuncture (stimulation at $5 \mathrm{~Hz}$ ) through two needles inserted on opposite sides of the cyst. Eleven days after the end of the treatment, the ganglion cyst could no longer be seen and the athlete reported no further discomfort. ${ }^{23}$

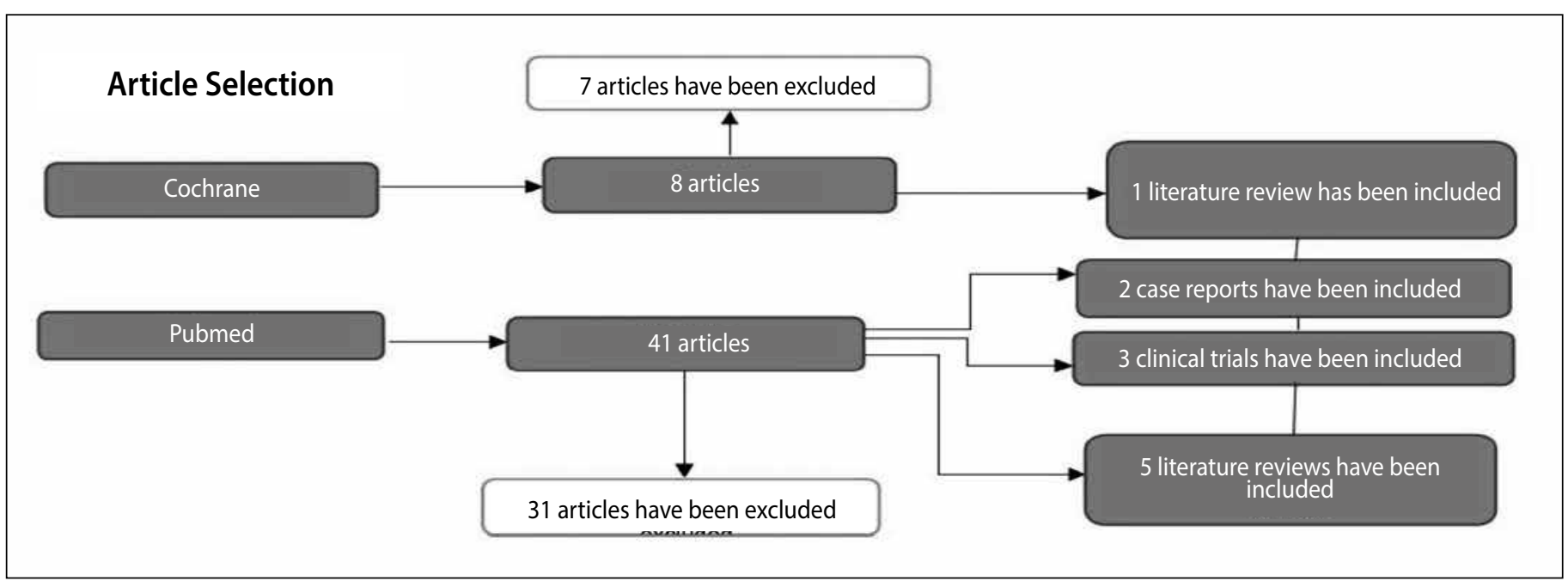

Figure 1. article selection for this study. 
In 2014, Gliedt and Daniels reported the case of a 41 -year-old male patient treated for pain and edema in the left elbow after suffering injuries during a basketball game with a 15-minute acupuncture session in the critical area (which reduced the level of pain from 5/10 to 1/10), followed by another acupuncture session using Active Release Techniques, which reduced the level of pain to 0/10 and enabled the patient to resume his daily and sport activities free of pain. Six weeks later, an over the phone follow-up revealed that the patient did not present any recurrent lesions or symptoms. ${ }^{24}$

\section{Clinical Trials}

Table 1 summarizes the clinical trials included in the study and their results.

In 2013, Morimoto et al. conducted a clinical trial including 41 patients suffering from sports-related injuries using low-level laser therapy applied to acupuncture points and pain points. Two to ten treatment sessions were self-administered or conducted by a physician. The therapy was considered effective (with a 5/10 or lower post-treatment pain score) according to 27 patients (65.9\%); however, the perception of effectiveness reached $100 \%$ for sessions conducted by a physician. ${ }^{25}$

In 2014, Valera-Garrido et al. published a clinical trial using ultrasound-guided electroacupuncture to treat 36 patients suffering from chronic lateral epicondylitis. Patients were treated with ultrasound-guided electroacupuncture on the surface of the common extensor muscle tendon and on the surface of the short radial carpal extensor (first approach), as well as above the capsule and on the collateral ulnar ligament (second approach), once a week, for four weeks, in conjunction with eccentric exercises and stretches taught by a physiotherapist, meant to be performed at home. After four weeks, patients were required to perform the same eccentric exercises once a day, for another six weeks. At the end of the treatment, 31 of 36 patients (86.1\%) reported decreased pain by provocation. After six weeks, 30 patients (83.3\%) confirmed the therapy was successful. The other 6 reported a localized pain spot, receiving another session of electroacupuncture. Thirty-two of 36 patients were located for reevaluation after 26 and 52 weeks, with a $100 \%$ perception of success. ${ }^{26}$

In 2016, Yang et al. published a clinical trial on six Korean medical doctors who worked as the Korean women's volleyball team physicians between 2013 and 2014. The physicians recorded the injuries suffered by each athlete, the type of treatment used, and whether additional therapy combined with Western medicine was required. One-hundred and sixty-six injuries were recorded in 94 athletes; 151 of these cases were treated with acupuncture rather than with any other Korean medicine therapy. Two of the cases required treatment using western medicine in a hospital located outside the training center following the acupuncture sessions; 23 cases required treatment combined with exercises following the sessions and 23 cases required physiotherapy following the sessions. The study concluded that Korean medicine must be used cooperatively with other forms of prevention and treatment of sports injuries as a way to promote the advancement of Sports Medicine in Korea. ${ }^{27}$

Table 1. Shows the number of injuries studied in each clinical trial and its outcome.

\begin{tabular}{c|c|c|c}
\hline Authors & Injuries studied & Use of Acupuncture & Satisfactory Result \\
\hline Morimoto et al. & 41 & 41 & $27(65.9 \%)$ \\
\hline Valera-Garrido et al. & 36 & 36 & $32(88.9 \%)$ \\
\hline Yang et al. & 166 (in 94 patients) & 151 injuries & $103(68.2 \%)$ \\
\hline
\end{tabular}

\section{Literature Review}

The characteristics of the studied literature reviews are summarized in Table 2.

In 2015, Dimitrios investigated the use of eccentric exercises for the treatment of tendinopathies, concluding that eccentric exercises alone are not effective, unless combined with stretching exercises, acupuncture (including low-power laser and needles), shock wave therapy, ultrasound and iontophoresis. The author also observed that acupuncture is effective for reducing tendinopathy symptoms, even though it is unable to reverse the pathology. ${ }^{28}$

In 2016, the same author researched the physiotherapy treatment for lateral epicondylitis reporting once again that acupuncture, although not sufficient to reverse the pathology, reduces its symptoms by minimizing pain and improving joint function. Dimitrios concluded that more studies are required to define the effectiveness of this therapeutic method. ${ }^{29}$

Mortazavi et al. referred to the literature available in 2013 to analyze the treatment for low back pain in athletes. The information found suggests that acupuncture is very effective as compared to other treatments, reducing back pain if applied in conjunction with other therapies, but it is not superior to conservative treatment. They concluded that the level of evidence for the use of acupuncture to treat low back pain in athletes is $C$ (consensus, small studies, usual practice, expert opinion or reports and case series - uncontrolled clinical studies). ${ }^{30}$

Dong et al. have published a meta-analysis of 33 studies on various treatments for shoulder impact syndrome, concluding that exercise and other exercise-based therapies are the most important treatment options for this syndrome. The meta-analysis also concluded that in the early stages, exercise combined with other therapies is recommended as a non-surgical treatment, especially acupuncture and kinesiotaping (with statistical relevance). ${ }^{31}$

Park et al. have published a systematic review of the use of acupuncture for ankle sprains, including electroacupuncture, manual needle and hot needle, concluding that although acupuncture is significantly beneficial as an adjunctive treatment, there is insufficient evidence as to why it should be recommend as a treatment for evidence-based ankle sprain, which confirms the need for further well-designed studies. ${ }^{32}$

Page et al. analyzed randomized clinical trials that used electrotherapy to treat rotator cuff diseases, including low-intensity laser, transcutaneous

Table 2. Shows the number of studies and patients included in each literature review.

\begin{tabular}{|c|c|c|c|}
\hline Authors & $\begin{array}{c}\text { Publications } \\
\text { included }\end{array}$ & Patients & Conclusions \\
\hline Dimitrios & $\begin{array}{l}\text { Not described } \\
\text { in the study }\end{array}$ & $\begin{array}{l}\text { Not described } \\
\text { in the study }\end{array}$ & $\begin{array}{l}\text { Acupuncture reduces } \\
\text { tendinopathy symptoms }\end{array}$ \\
\hline Dimitrios & $\begin{array}{l}\text { Not described } \\
\text { in the study }\end{array}$ & $\begin{array}{l}\text { Not described } \\
\text { in the study }\end{array}$ & $\begin{array}{l}\text { Acupuncture reduces lateral } \\
\text { epicondylitis symptoms } \\
\text { and improves function }\end{array}$ \\
\hline $\begin{array}{c}\text { Mortazavi } \\
\text { et al. }\end{array}$ & $\begin{array}{l}101 \text { varied } \\
\text { studies }\end{array}$ & $\begin{array}{l}\text { Not described } \\
\text { in the study }\end{array}$ & $\begin{array}{l}\text { Acupuncture combined with other } \\
\text { therapies reduces low back pain }\end{array}$ \\
\hline Dong et al. & $\begin{array}{l}33 \text { clinical } \\
\text { trials }\end{array}$ & 2300 & $\begin{array}{l}\text { Exercise combined with acupuncture } \\
\text { are very effective during shoulder } \\
\text { impact syndrome treatment }\end{array}$ \\
\hline Park et al. & $\begin{array}{l}17 \text { clinical } \\
\text { trials }\end{array}$ & 1820 & $\begin{array}{l}\text { Acupuncture seems effective as an } \\
\text { alternative treatment for chronic } \\
\text { pain, speeding the healing process } \\
\text { and promoting quality of life }\end{array}$ \\
\hline Page et al. & $\begin{array}{l}47 \text { clinical } \\
\text { trials }\end{array}$ & 2388 & $\begin{array}{l}\text { Low-frequency laser therapy } \\
\text { has demonstrated to be more } \\
\text { efficient than placebo }\end{array}$ \\
\hline
\end{tabular}


electrical stimulation and ultrasound. Due to the poor quality of the studies analyzed, although low-power laser therapy appears to be more effective than placebo, it was not possible to conclude whether such therapy, ultrasound or transcutaneous electrical stimulation reduce pain or rotator cuff function. Hence, high quality research studies are required..$^{33}$

\section{DISCUSSION}

The case report prepared by Woitzik and Kissell ${ }^{23}$ did not observe the mean time of spontaneous resolution of the cyst, which reached 6 years based on a study conducted with 236 patients ${ }^{34}$, suggesting that acupuncture has only been concomitant to the resolution process without influencing it.

The second study was satisfactory but its statement of limitations confirms that the use of two concomitant therapeutic techniques (acupuncture and active release technique) for the same lesion (lateral epicondylitis) ${ }^{24}$ makes it difficult to define which one was effective or if one has potentiated the effect of the other in some way.

According to Longo, the therapies currently available for the treatment of lateral epicondylitis vary and lack scientific evidence. ${ }^{35}$ Non-steroidal anti-inflammatory drugs (NSAIDs) and corticosteroid injections are traditionally used, but they appear to be just as helpful as watchful observation. ${ }^{36,37}$ A study prepared by Magra using NSAIDs to treat this type of injury observed small or no reduction of pain, ${ }^{38}$ whereas his 2005 meta-analysis demonstrated that acupuncture causes significant short-term pain relief in lateral epicondylitis. ${ }^{36}$

The research on the clinical trials selected for this review have presented positive results for acupuncture treatment, being such results more favorable when acupuncture is associated with another type of therapy ${ }^{26,27}$ and when applied by a physician rather than being self-administered ${ }^{25}$

Such positive results are corroborated by studies that demonstrate that acupuncture produces temporary analgesia and relief according to the descending modulation system of pain ${ }^{39-43}$, and by a 2015 study that observed, based on Magnetic Resonance Imaging and interviews, that there was an improvement in the modulation of functional connectivity and a decrease in the perception of pain in a group of subjects treated with acupuncture for knee osteoarthrosis, as compared to another group treated with sham acupuncture ${ }^{44}$.

However, the difference between self-application and application performed by a trained professional was not observed in a 2013 study with 197 cancer patients distributed into self-application, professional application and control groups, and no statistical difference was shown between the self-application group and the professional application group as far as the improvement reported on fatigue, anxiety and depression symptoms is concerned. ${ }^{45}$
The literature reviews included in the present study reported that not very many acupuncture clinical trials and literature reviews with adequate designs are available, and that it is difficult to obtain high quality evidence through the articles published. ${ }^{28-33}$ The two Dimitrios revisions, with their non-formatted design, did not clearly describe which studies were included, how many publications were analyzed, or how many patients were included the sum of these publications. ${ }^{28,29}$

Cochrane literature reviews have shown that acupuncture therapy is an effective treatment for fibromyalgia, neck pain and chronic low back pain ${ }^{40-42}$, but reviews of the same platform have not found significant evidence or have not obtained sufficient information to conclude how effective its use really is in the treatment of osteoarthritis, shoulder pain and elbow pain ${ }^{49-51}$.

In 2001, this lack of information led Nahin and Straus, directors of the US government's agency responsible for the research on medical products and unconventional therapeutic practices, such as acupuncture, to disclose which research challenges are most likely to hinder study designs in acupuncture. Some of them include: methodological failures of the first clinical trials; difficulties in analyzing the use of a set of therapies or the fact that each patient is treated based on a individualized regimen; problems in accumulating, randomizing, and retaining trial participants; and the lack of identification of adequate placebo interventions. ${ }^{52}$

Also in 2001, an international group of acupuncture researchers developed a set of recommendations that could improve the quality of the studies, including critical evaluation, analysis and replication conditions. These recommendations (shown below in Figure 02) are known as Standards for Reporting Interventions in Controlled Trials of Acupuncture (STRICTA) and have been designed as an extension of the CONSORT (Consolidated Standards for Reporting of Trials) statement intervention item checklist. ${ }^{53}$

The definition of control group within the acupuncture context is very important: The reviews published by Moffet have shown good results both in true acupuncture and sham acupuncture, with no significant difference between them ${ }^{54,55}$, which exposes an issue addressed during a roundtable held in 2009: the efficacy of sham acupuncture and the difficulty defining an adequate placebo group in acupuncture ${ }^{56}$.

Hammerschlag realized that the greatest challenge for future trials would be the creation of means capable of mimicking acupuncture in clinical practice. ${ }^{57}$

The author defined the types of control most commonly used in acupuncture clinical trials and their evaluation objectives:

Type I. Waiting list or no treatment: The efficacy of acupuncture is assessed according to the natural history of the disease, but not to control non-specific treatment effects.

\footnotetext{
Intervention Item $\longrightarrow$ Explanation

The Logic of Acupuncture $\longrightarrow$ Statement on the style and approach of acupuncture used (Western or Oriental). Explicit reasons for the treatment of choice, including diagnosis, point selection, and treatment procedures and their variables, if any.

Needling details $\longrightarrow$ Specific location of points, number, duration and depth of insertions, needle response desired, stimulation techniques and full description of the needle used.

Treatment Regimen Number of sessions, frequency of treatment and variations.

Co-interventions $\longrightarrow$ Complementary and self-treatment techniques prescribed, quality of life consultancy, etc.

Acupuncturist background $\longrightarrow$ Training duration, length of clinical experience, and details on the professional expertise in treating the condition evaluated, including any other experience that may be relevant to the assessment.

Intervention control $\longrightarrow$ The choice of control and its intended effect must be presented and justified according to the research and the methodology. Include an accurate description of the intervention control, including needling details and its regimen, if they differ from those used in the acupuncture group.
}

Figure 2. STRICTA Recommendations. 
Type II. Placebo Controls: Defined as non-invasive procedures, such as inactive transcutaneous electrical nerve stimulation (TENS) and inactive laser acupuncture used to assess whether acupuncture has an effect far superior than that caused by the therapeutic medium (needle insertion into the skin).

Type III. Sham Controls: Defined as invasive and inadequate procedures, such as the insertion of superficial needles, at points outside the acupuncture points, or acupoints not recommended for the condition treated. Evaluates whether the effectiveness of acupuncture relies upon the style and location of the insertion.

Type IV. Standard Western Treatment: Compares the effects of acupuncture with medications and other medical procedures or physical therapy.

Type V. Evaluates standard treatment associated with acupuncture. ${ }^{57}$

Taking into account such information and challenges, Linde believes that since acupuncture trials without a placebo control group cannot be blind, they are expected to achieve lower scores on quality scales. ${ }^{58}$

According to the literature available, acupuncture seems to be an effective treatment for acute myofascial pain in athletes ${ }^{13,19,20,59,60}$; to decrease the subjective sensation of pain ${ }^{13,61}$; in addition to promoting recovery of muscles that present possible irregular contracture and/or function ${ }^{62}$.

According to Osborne, this type of therapy is fast, effective, with no side effects and can be safely used on competition day with positive results. ${ }^{13}$

For these reasons, a publication available to Orthopedic Surgeons in the United States has concluded that acupuncture, although controversial, represents an adjuvant therapy for musculoskeletal conditions. ${ }^{63}$

In order to mitigate randomized clinical trials and placebo group issues in acupuncture, other types of high-quality research, such as observational studies and animal experiments, may be a viable

\section{REFERENCES}

1. Zhang R. Accidents in acupuncture treatment: history and current state. Zhong Xi Yi Jie He XueBao 2004; 2(4): 306-313.

2. Huang C, Wang Y, Han J et al. Characteristics of electroacupuncture-induced analgesia in mice: variation with strain, frequency, intensity and opioid involvement. Brain Research. 2002; 945: 20-25.

3. Ulett G, Han S, Han J. Electroacupuncture: mechanisms and clinical application. Biological Psychiatry. 1998; 44: 129-138.

4. Akimoto T, Nakahori C, Aizawa et al. Acupuncture and responses of immunologic and endocrine markers during competition. Medicine \& Science in Sports \& Exercise 2003: 1296-1302.

5. Wright KD, Stewart SH, Finley GA, Buffett-Jerrott S E. Prevention and intervention strategies to alleviate preoperative anxiety in children: a critical review. Behavior Modification. 2007; 31(1): 52-79.

6. Shayestehfar M, Seif-Barghi T, Zarei S, Mehran A. Acupuncture Anxiolytic Effects on Physiological and Psychological Assessments for a Clinical Trial. Scientifica. 2016; 2016: 4016952.

7. Karvelas RB, Hoffman MD, Zeni Al. Acute effects of acupuncture on physiological and psychological responses to cycle ergometry. Arch Phys Med Rehabil 1996; 77: 1256-1259.

8. Ahmedov S. Ergogenic effect of acupuncture in sport and exercise: a brief review. Journal of Strength \& Conditioning Research. 2010; 24: 1421-1427.

9. Ceolin do Nascimento R, Hossri CAC, Berwanger O, Carvalho VO. Acupuncture and exercise capacity: A case report. Clinics. 2012; 67(2): 193-194.

10. Luna MP, Fernandes Filho, J. Efeitos da acupuntura na performance de atletas velocistas de alto rendimento do Rio de Janeiro. Fitness \& performance journal 2005; 4(4): 199-214.

11. Ehrlich D, Haber P. Influence of Acupuncture on Physical Performance Capacity and Haemodynamic Parameters. Int. J. Sports Med 1992; 13: 486-491.

12. Frezza GR. Os benefícios da acupuntura para praticantes de musculação. 2004.

13. Osborne NJ, Gatt IT. Management of shoulder injuries using dry needling in elite volleyball players. Acupuncture in Medicine 2010; 28: 42-45.

14. De Almeida MD, De Freitas KM, Oliveira LP. Acupuncture increases the diameter and reorganization of collagen fibrils during rat tendon healing. Acupunct Med 2015; 33: 51-7.

15. Inoue M, Nakajima M, Oi Y, et al. The effect of electroacupuncture on tendon repair in a rat Achilles tendon rupture model. Acupunct Med 2015; 33: 58-64.

16. Usichenko Tl, Gizhko V, Wendt M. Goal-Directed Acupuncture in Sports - Placebo or Doping? Evidencebased Complementary and Alternative Medicine: eCAM. 2011; 2011: 265607.

17. Watts J. Feature: Olympian pins and needles. The Lancet 2005; 366(1):62-63. research options whenever patient randomization is considered unethical or unacceptable. ${ }^{55,56}$

If research involving human subjects is required, Fragoso suggests the following:

1. Perform an extensive western and eastern physiopathological survey of the disease or dysfunction target of the study.

2. Select validated biomarkers, capable of detecting the physiological and therapeutic effects resulting from the interventions in the pathological condition evaluated.

3. Ensure that the control group is receiving the best available treatment, whether it is Western or Eastern.

4. Consider the theoretical framework to determine whether the intervention tested will involve a complete approach (Acupuncture, moxibustion, among others) or partial (acupuncture only).

5. In the case of acupuncture interventions, describe the acupuncture location methodology, including the reason for the prescription, insertion and manipulation procedures and the type of needles used.

6. Use a sham group only when the null hypothesis is chosen - observing synergic, additive and subtractive noises when analyzing biomarkers. 7. In conditions where the psychosomatic effect of the intervention cannot be excluded from biomarking, choose a validated placebo procedure.22

\section{CONCLUSION}

The efficacy of acupuncture and its relation to the placebo effect are deemed controversial to date, despite the number of studies available suggesting its effectiveness. Further studies are still necessary in order to conclude the efficacy of acupuncture in sports injuries. Thus, research in acupuncture should be encouraged so that it is possible to use it safely within Sport Medicine.

All authors declare no potential conflict of interest related to this article

18. Itoh K, Katsumi Y, Hirota S, et al. Effects of trigger point acupuncture on chronic low back pain in elderly patients - a sham-controlled randomized trial. Acupunct Med 2006; 24:5-12.

19. Tough EA, White AR, Cummings TM, et al. Acupuncture and dry needling in the management of myofascial trigger point pain: a systematic review and meta-analysis of randomized controlled trials. Eur J Pain 2009;13: 3-10

20. Huguenin L, Brukner PD, McCrory P, et al. Effect of dry needling of gluteal muscles on straight leg raise: a randomized, placebo controlled, double blind trial. Br J Sports Med 2005; 39: 84-90.

21. Barros, NFD. Política Nacional de Práticas Integrativas e Complementares no SUS: uma ação de inclusão. Ciência \& Saúde Coletiva 2006; 11(3): 850-850.

22. Fragoso, APS. Ensaios clínicos com acupuntura: questões bioéticas e metodológicas. Perspectivas online. 2010; 4(15): 151-158.

23. Woitzik E, Kissel J. Ganglion cyst of the foot treated with electroacupuncture: A case report. The Journal of the Canadian Chiropractic Association. 2013; 57(4): 310-315.

24. Gliedt JA, Daniels CJ. Chiropractic management of elbow tendinopathy following a sports related trauma. The Journal of the Canadian Chiropractic Association. 2014; 58(1): 52-57.

25. Morimoto Y, Saito A, TokuhashiY. Low level laser therapy for sports injuries. Laser Therapy. 2013; 22(1): 17-20

26. Valera-Garrido F, Minaya-Muñoz F, Medina-Mirapeix F. Ultrasound-guided percutaneous needle electrolysis in chronic lateral epicondylitis: short-term and long-term results. Acupuncture in Medicine. 2014; 32(6): 446-454.

27. Yang C, Lee E, Hwang E, Kwon O, Lee J. Management of Sport Injuries with Korean Medicine: A Survey of Korean National Volleyball Team. Evidence-Based Complementary and Alternative Medicine 2016; 2016, Article ID 8639492, 7 pages.

28. Dimitrios S. Exercise for tendinopathy. World Journal of Methodology. 2015; 5(2): 51-54.

29. Dimitrios S. Lateral elbow tendinopathy: Evidence of physiotherapy management. World Journal of Orthopedics. 2016; 7(8): 463-466.

30. Mortazavi J, Zebardast J, Mirzashahi B. Low Back Pain in Athletes. Asian Journal of Sports Medicine. 2015; 6(2): e24718.

31. Dong W, Goost H, Lin X-B, et al. Treatments for Shoulder Impingement Syndrome: A PRISMA Systematic Review and Network Meta-Analysis. Sahin. A, ed. Medicine. 2015; 94(10): e510.

32. Park J, Hahn S, Park J-Y, Park H-J, Lee H. Acupuncture for ankle sprain: systematic review and meta-analysis. BMC Complementary and Alternative Medicine. 2013; 13:55.

33. Page MJ, Green S, Mrocki MA, Surace SJ, Deitch J, McBain B, Lyttle N, Buchbinder R. Electrotherapy modalities for rotator cuff disease. Cochrane Database of Systematic Reviews 2016, Issue 6. 
34. Dias JJ, Dhukaram V, Kumar P. The natural history of untreated dorsal wrist ganglion and patient reported outcome 6 years after intervention. J Hand Surg Eur. 2007;32:502- 508.

35. Longo UG, Franceschetti E, Rizzello G, Petrillo S, Denaro V. Elbow tendinopathy. Muscle, Ligaments and Tendons Journal. 2012;2(2): 115-120.

36. Bisset L, Paungmali A, Vincenzino B, Beller E. A systematic review and meta-analysis of clinical trials on physical interventions for lateral epicondylalgia. Br J Sports Med. 2005;39:411-22.

37. Bisset L, Beller E, Jull G, Brooks P, Darnell R, Vicenzino B. Mobilization with movement and exercise, corticosteroid injection, or wait and see for tennis elbow: randomized trial. BMJ Clinical Research. 2006;333(7575): 939.

38. Magra M, Muffulli N. Nonsteroidal anti-inflammatory drugs in tendinopathy. Clin J Sports Med. 2006;16:1-3

39. Han JS. Acupuncture analgesia: areas of consensus and controversy. Pain. 2011; 152(3 Suppl): S41-S48.

40. Han JS. Physiology of acupuncture: review of thirty years of research. J Altern Complement Med. 1997; (Suppl 1): S101-8.

41. Zhao ZQ. Neural mechanism underlying acupuncture analgesia. ProgNeurobiol. 2008; 85(4): 355-375.

42. Dougherty DD, Kong J, Webb M, Bonab AA, Fischman AJ, Gollub RL. A combined [11 C]diprenorphine PET study and fMRI study of acupuncture analgesia. Behav Brain Res. 2008; 193(1): 63-8 (PMCID: PMC2538486).

43. Napadow V, Kettner N, Liu J, et al. Hypothalamus and amygdala response to acupuncture stimuli in carpal tunnel syndrome. Pain 2007; 130: 254-66.

44. Chen X, Spaeth RB, Freeman SG, et al. The modulation effect of longitudinal acupuncture on resting state functional connectivity in knee osteoarthritis patients. Molecular Pain. 2015; 11:67.

45. Molassiotis A, Bardy J, Finnegan-John J, Mackereth P, et al. A randomized, controlled trial of acupuncture self-needling as maintenance therapy for cancer-related fatigue after therapist-delivered acupuncture. Ann Oncol 2013; 24 (6): 1645-1652

46. Deare JC, Zheng Z, Xue CC, et al. Acupuncture for treating fibromyalgia. Cochrane Database Syst Rev. 2013; 5:CD007070.

47. Trinh KV, Graham N, Gross AR, et al. Acupuncture for neck disorders. Cochrane Database Syst Rev. 2006: 3:CD004870.

48. Furlan AD, van Tulder MW, Cherkin DC, et al. Acupuncture and dry-needling for low back pain. Cochrane Database Syst Rev. 2005; 1:CD001351.

49. Green S, Buchbinder R, Hetrick S. Acupuncture for shoulder pain. Cochrane Database Syst Rev. 2005; 2:CD005319
50. Green S, Buchbinder R, Barnsley L, et al. Acupuncture for lateral elbow pain. Cochrane Database Syst Rev. 2002; 1:CD003527.

51. Manheimer E, Cheng K, Linde K, et al. Acupuncture for peripheral joint osteoarthritis. Cochrane Database Syst Rev. 2010; 1:CD001977.

52. Nahin RL, Straus SE. Research into complementary and alternative medicine: problems and potential. BM. British Medical Journal. 2001; 322(7279): 161-164.

53. Zwarenstein M, Treweek S, Gagnier JJ, et al. Improving the reporting of pragmatic trials: an extension of the CONSORT statement. The BMJ. 2008; 337: a2390.

54. Moffet HH. Traditional acupuncture theories yield null outcomes: a systematic review of clinical trials. J Clin Epidemiol 2008; 61:741-747.

55. Moffet HH. Sham acupuncture may be as efficacious as true acupuncture: a systematic review of clinical trials. J Altern Complement Med 2009; 15: 213-216.

56. Wayne PM, Hammerschlag R, Langevin HM, Napadow V, Park JJ, Schnyer RN. Resolving paradoxes in acupuncture research: A roundtable discussion. Journal of Alternative and Complementary Medicine. 2009 Sep 1; 15(9): 1039-1044

57. Hammerschlag R. Methodological and ethical issues in clinical trials of acupuncture. Journal of Alternative and Complementary Medicine. 1998:4(2):159-171.

58. Linde K, Vickers A, Hondras M, et al. Systematic reviews of complementary therapies - an annotated bibliography. Part 1: Acupuncture. BMC Complementary and Alternative Medicine. 2001;1:3.

59. Jimbo S, Atsuta Y, Kobayashi T, et al. Effects of dry needling at tender points for neck pain (Japanese: katakori): near-infrared spectroscopy for monitoring muscular oxygenation of the trapezius. J OrthopSci 2008; 13: 101-6.

60. Lee SH, Chen CC, Lee CS, Lin TC, Chan RC. Effects of needle electrical intramuscular stimulation on shoulder and cervical myofascial pain syndrome and microcirculation.J Chin Med Assoc. 2008 Apr; 71(4): 200-6

61. Ingber RS. Shoulder impingement in tennis/racquetball players treated with subscapularis myofascial treatments. Arch Phys Med Rehabil 2000;81:679-82.

62. Ma Y, Ma M, Cho ZH. Acupuntura para Controle da Dor: um enfoque integrado. São Paulo, Roca, 2006; 49-66; 297- 305.

63. Domes C, Kruger C. Therapists, Trainers, and Acupuncturists: Focused Review for the Orthopedic Surgeon. ORTHOPEDICS. 2015; 38: e1121-e1126. 